\title{
Isolation of Active Compounds from Original Plants of East Kalimantan as Cosmetics
}

\author{
Ritson Purba ${ }^{1,3}$ Enos Tangke Arung ${ }^{2, *}$ Harlinda Kuspradini ${ }^{2}$ Daniel Tarigan ${ }^{3}$ \\ ${ }^{1}$ Doctoral Program in Forestry Science, Mulawarman University, Jl. Ki Hajar Dewantara, Campus of Gn. Kelua Jl. \\ Ki Hajar Dewantara Samarinda 75119, East Kalimantan, Indonesia \\ ${ }^{2}$ Laboratory of Forest Product Chemistry, Faculty of Forestry, Mulawarman University Campus of Gn. Kelua Jl. \\ Penajam Samarinda 75119, East Kalimantan, Indonesia \\ ${ }^{3}$ Faculty of Mathematic and Natural Science, Mulawarman University, Jl. Barong Tongkok, Campus of Gn. Kelua, \\ Samarinda, 75123, East Kalimantan, Indonesia \\ *Corresponding author. Email: enostangkearung@gmail.com
}

\begin{abstract}
Phytochemical and antioxidant activity tests were conducted on ethanol extracts of the trunk, flower and leaf of Senggani (Melastoma candidum D.Don). Each sample was macerated with ethanol, and then it was concentrated with a rotary evaporator. The secondary metabolites of each sample's phytochemical test (Senggani) showed that the ethanol extract taken from the trunk was phenolics and triterpenoids. In contrast, the sample taken from the flower were steroid, and from the leaf were saponins. The result showed that in ethanol extract taken from the trunk exhibited antioxidant activities subtuance at $39.087 \%$, the ethanol extract from the flower was at $6.548 \%$ and the ethanol extract taken from the leaf at $60.913 \pm 0.002 \mu \mathrm{g} / \mathrm{ml}$ for the ethanol extract of the trunk, $\mathrm{EC}_{50} \mu \mathrm{g} / \mathrm{ml}$ at $93.452 \pm 0.005$ $\mu \mathrm{g} / \mathrm{ml}$ for the ethanol of the flower and, $\mathrm{EC}_{50}(\mu \mathrm{g} / \mathrm{ml})$ at $42.063 \pm 0.015 \mu \mathrm{g} / \mathrm{ml}$ for the ethanol of the leaf.
\end{abstract}

Keywords: Melastoma candidum, Senggani, Leaves, Stem, Flower

\section{INTRODUCTION}

Plants are one of the most important natural resources, which have particular value both economically and as the planet earth's lungs. Plants are the place for the synthesis of complex organic compounds to produce a series of compounds with various structures. The search for new compounds against undeveloped plants will be more exciting and prospective because of the greater likelihood of finding new compounds [1].

Plants have an essential role in the survival of humankind. From the results of previous research, some plant species are known to have antioxidant activity. Natural antioxidants developed are obtained from different types of herbs from either low-level plants to large trees.

Natural antioxidant compounds derived from plants are generally phenolic or polifenoic compounds that can be flavonoid groups, including flavones, flavonols, isoflavones, katecine and kalkon. Cyanic acid derivatives include caffeine acid, ferulic acid, chlorogenic acid, coumarin, tocopherol and polyfunctional acids [2]. Flavanoid itself is the largest natural phenol group. Effects of flavonoids include deep prevent lipooksigenase. Flavanoid compounds are mostly good reducers that can inhibit many oxidation reactions. Flavanoids act as hydroxy and superoxide radical containers and protect lipid membranes against adverse responses [3].

Senggani plant (Melastomacandidum D.Don) is a wild plant that grows in places that get enough sun rays, such as on the slopes, shrubs, the field is not too arid, or in the tourist object as an ornamental plant. This plant is commonly found to a height of $1650 \mathrm{~m}$ above sea level [4].

This natural antioxidant action is considered safer than synthetic antioxidants because natural antioxidants are obtained from plant extracts. Therefore, research on natural antioxidants, both sourcing, extraction, isolation, and testing of biological activities, is widely performed abroad and in Indonesia. Foods that can be sources of natural antioxidants include several types, such as 
spices, tea, cocoa leaves, grains, seralia, enzymes and protein [5].

From the description above, the researcher conducted laboratory research on phytochemical test and identification of antioxidant activity from ethanol extract on stem, flower and leaf of Senggani plant (Melastoma candidum D.Don) to free radical of DPPH (2,2-diphenyl-1-picrylhydrazil) and measured using a UV-Vis spectrophotometer. It is expected that the extract from each part of the plant has the capability of good antioxidant activity and the ability to add further chemistry of natural materials.

\section{MATERIALS AND METHODS}

\subsection{Tools}

The tools used in this research are blenders, reagent bottles (maceration), test tubes and reaction tube shelves, drop pipettes, volume pipettes, digital scales (Ohauss), vortex tools, UV-Vis spectrophotometer, glass kuvet, measuring glass, Erlenmeyer, glass funnel, desiccator, oven (Memmert), autoclave, vapor plate, incubator (Heraus), extraction bottle, beaker glass, aluminium foil, rotary evaporator, vacuum pump, magnetic stirrer, 100-1000 $\mu \mathrm{m}$ pipette, stirrer rod, computer set and scanner tool, water shaker, hot plate, bunsen, statif and clamp.

\subsection{Materials}

Materials used in the present study are ethanol, DPPH, DMSO, Vitamin C (ascorbate), aquades, chloroform ammoniac, Lieberman-Butchard, n-hexane, methanol, $\mathrm{HCl}, \mathrm{H}_{2} \mathrm{SO}_{4}, \mathrm{Mg}$ powder, $\mathrm{FeCl}_{3}, \mathrm{HgCl}_{2}$, Diethyl ether, Dragen Dorff, Erlenmeyer, what man paper, silica gel and a sample of stems, leaves and flowers of Senggani plant (Melastoma candidum D.Don).

\subsection{Sample Preparations}

Each piece of stems, flowers and leaves of Senggani plants, before being extracted, are cleaned by washing with water and rinsed with aquades. Then air-dried in the open air in the room so as not exposed to direct sunlight, then after the dry mashed manually and weighed.

\subsection{Maceration and Concentration of Solutions}

Samples that have been finely extracted by maceration method by soaking each stem, flower and leaf sample with ethanol solvent and repeated extraction until the extract solution no longer colour. The resulting titrate then filtered using a glass funnel and filter paper and a vacuum to separate the plant material's extract.
The extraction results were then concentrated with a rotary evaporator at $40^{\circ} \mathrm{C}$ until a viscous extract was obtained. Then the extension is entered into the desiccator before further research [6].

\subsection{Phytochemical Test}

\subsubsection{Alkaloid Test (Meyer's Test and Dragendorff Test)}

Thirty mg of crude ethanol extract was obtained in each sample section plus $10 \mathrm{ml}$ of chloroform-ammonia, then filtered into the test tube. The filtrate is added with $2 \mathrm{M}$ sulfuric acid drops and shaken to form a layer. The acid layer (found at the top) was piped into another test tube, then Meyer's reagent ( $5 \mathrm{~g}$ KI was dissolved in 90 ml water and slowly added $\mathrm{HgCL}_{2}$ while stirring and diensered to $100 \mathrm{ml}$ ) and Dregendorff reagent mixture $\left(\mathrm{BiNO}_{3}\right) 2.5 \mathrm{H}_{2} \mathrm{O}$ in nitric acid and $\mathrm{KI}$. The presence of alkaloids is indicated by the formation of white precipitate and Meyer's reaction and orange deposition to red-brown with Dreagendorff reagent $[4,7]$.

\subsubsection{Saponin Test (Fourth Test)}

Taken $30 \mathrm{mg}$ of crude extract ethanol in each sample section was extracted with diethyl ether as much as three times, from the fraction of the extract produced a soluble fraction in diethyl ether and which was not soluble in diethyl ether. The insoluble fraction in diethyl ether is then added approximately $5 \mathrm{ml}$ of water in the reaction tube and shaken. Positive extracts contain saponins in the presence of foam with a height of 1-3 $\mathrm{cm}$ that lasts for 15 minutes [8].

\subsubsection{Steroid and Triterponoid Test/Lieberman- Buchard Test}

A total of $30 \mathrm{mg}$ of crude ethanol extract from each of the sample parts was added $\mathrm{CHCL}_{3}$, then added Lieberman-Buchard reagent. The solution is shaken gently and left for several minutes. Steroids provide a blue or green colour, and Triterponoid gives a red or purple colour [9].

\subsubsection{Flavonoid Test}

Taken A total of $30 \mathrm{mg}$ of crude ethanol extract from each sample section plus $100 \mathrm{ml}$ of hot water, boil for 5 minutes, then filtered. Filtrates of $5 \mathrm{ml}$ plus a little powder of $\mathrm{Mg}$ and $1 \mathrm{ml}$ of concentrated $\mathrm{HCl}$, then shaken vigorously. The positive test is shown by the formation of red, yellow or orange [5].

\subsubsection{Phenolic Test}

Taken A total of $30 \mathrm{mg}$ of crude ethanol extract from each sample portion added a few drops of $\mathrm{FeCl} 3$ 
$1 \%$ in water or ethanol. The positive extract contains ethanol when it produces green, red, purple, blue, or black [10].

\subsection{Antioxidant Activity Test With DPPH Method}

Testing of antioxidant activity was done based on the modification of the whitewater method (2006). Using the spectrophotometer at room temperature (25 ${ }^{\circ} \mathrm{C}$ ) with 580-517 nm long wavelength but sought the maximum wave first and DPPh solution (1,1-diphenyl2-pictylhydrazyl) was used as free radical for the test.

DPPH solution was made by weighing DPPH and dissolved in ethanol precisely at the concentration of $0.0027 \%$. The sample extract of $3 \mathrm{mg}$ was dissolved in DMSO to obtain $100 \mathrm{ppm}$ concentration.

Incorporated test sample into cuvette as much as 33 $\mu \mathrm{L}$. Ethanol of $467 \mu \mathrm{L}$ was added to the cuvette, and then $500 \mu \mathrm{L}$ solution of DPPH $60 \mu \mathrm{M}$ (diluted in ethanol) was added. The volume is sufficient to $1000 \mu \mathrm{L}$ $(1 \mathrm{ml})$, after which the test sample is incubated for 20 min at room temperature. The same treatment was applied to the control solution, using DMSO as the sample solution.

The antioxidant activity is determined by DPPH decolourisation at a predetermined wavelength using a spectrophotometer as a positive control and as comparable use ascorbic acid (Vitamin C) known as a natural antioxidant. Antioxidant activity is determined by the percentage of free radical inhibitory power. Quantitative analysis of radical inhibitory activity/DPPH is done by referring to Kusuma [7]. The following formula calculates antioxidant activity.

The reduction percentage of DPPH absorption [7]:

$\%$ Damping=

$\frac{\text { ABS control - ABS sample }}{\text { ABS control }} \times 100 \%$

Where:

ABS control $=$ Absorbance value without extract

ABS sample $=$ Absorbance value with extract

This test aims to indicate the presence of antioxidant activity indicated by the decolourisation of DPPH radical colour from purple to yellow to clear and a decrease in absorbance value of extract to control, as displayed by the monitor the spectrophotometer. If there is such an indication, it can be stated that there has been an inhibition of extract on DPPH radicals, which means the extract has antioxidant potential because it has been able to inhibit the work of free radicals.

\subsection{Data Processing}

All testing is done three times replication. The test scores with an average of 3 replicate and the common intersection values tabulated and poured in graphs or tables. The result data of the chemical compound content test will be expressed by the sign (+) to indicate certain compounds in plant extracts or (-) when inexplicable.

\section{RESULT AND DISCUSSION}

Each sample's dry weight, i.e., stems, flowers, and leaf senggani plants that have been smoothed in this study each is 50 grams. Each sample was then macerated with ethanol, filtered using the vacuum pump, concentrated with a rotary evaporator, and obtained a dark brownish yellowish extract. The weight of the concentrated extract from each sample is presented in Table 1 below.

Table 1. The Weight of The Concentrated Extract from Senggani Plant

\begin{tabular}{clccc}
\hline No & Sample & $\begin{array}{c}\text { Initial } \\
\text { Weight } \\
\text { (gr) }\end{array}$ & $\begin{array}{c}\text { Final } \\
\text { Weight } \\
\text { (gr) }\end{array}$ & $\begin{array}{c}\text { Rendemen } \\
\text { (\%) }\end{array}$ \\
\hline 1 & Senggani stem & 50 & 7,53 & 15.56 \\
2 & Senggani flower & 50 & 6,11 & 12,22 \\
3 & Senggani leave & 50 & 7,76 & 15,52 \\
\hline
\end{tabular}

Table 2. Phytochemical Test Result from Ethanol Extract of Senggani Stem

\begin{tabular}{lccc}
\hline \multicolumn{1}{c}{$\begin{array}{c}\text { Secondary Metabolites } \\
\text { Compound Types }\end{array}$} & 1 & 2 & 3 \\
\hline Alkoloid & - & - & - \\
Flavonoid & - & - & - \\
(Hennolik & + & + & + \\
Saponin & - & - & - \\
Steroid & - & - & - \\
Triterponoid & + & + & + \\
\hline
\end{tabular}

Table 3. Phytochemical Test Result from Ethanol Extract of Senggani Flower

\begin{tabular}{lccc}
\hline \multicolumn{1}{c}{$\begin{array}{c}\text { Secondary Metabolites } \\
\text { Compound Types }\end{array}$} & 1 & 2 & 3 \\
\hline Alkoloid & - & - & - \\
Flavonoid & - & - & - \\
Fenolik & - & - & - \\
Saponin & - & - & - \\
Steroid & + & + & + \\
Triterponoid & - & - & - \\
\hline
\end{tabular}


Table 4. Phytochemical Test Result from Ethanol Extract of Senggani Leave

\begin{tabular}{lccc}
\hline $\begin{array}{c}\text { Secondary Metabolites } \\
\text { Compound Types }\end{array}$ & 1 & 2 & 3 \\
\hline Alkaloid & - & - & - \\
Flavonoid & + & + & + \\
Fenolik & - & - & - \\
Saponin & + & + & + \\
Steroid & - & - & - \\
Triterpenoid & - & - & - \\
\hline
\end{tabular}

Alkaloid test on stem, flower and senggani leaves showed negative results where no saponin test for senggani leaf showed positive results on ethanol extract. For stems and senggani flowers showed negative results on ethanol extract formed a precipitate. The sultry flower showed a positive result on the ethanol extract for steroids giving the blue-greenish colour. The rod of senggani showed positive results for the triterpenoids giving the red colour. The phenolic stem test of senggani results from a rough extract of ethanol by producing a dark red colour while for flower and negative senggani leaves. Flavonoid test of senggani leaves gives positive results while negative stems and leaves with red, yellow or orange. Based on phytochemical results, ethanol extracts in each sample contained phenolic secondary metabolite compounds, flavonoids, saponins, steroids, and triterpenoids.

Performed UI antioxidant at a concentration of 100 ppm, it turns out the extract immediately provides neutralisation against DPPH radicals. Table 2 shows that the highest percentage of inhibition on an ethanol extract of senggani stem while the lowest rate was found in ethanol extract of senggani flower. The per cent of damping of each sample is presented in Table 5 below.

The average from the percentage of DPPH neutralisation is presented in the following graph.

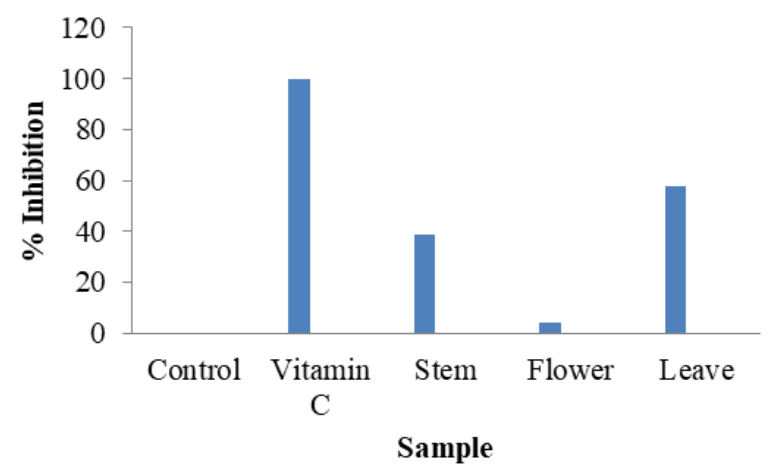

Figure 1 Inhibitory activity of the sample
The inhibition percentage result indicates that each extract has different inhibitory activity against free radical (DPPH) compared with control. The value of damping is obtained from the above data processing in ethanol extract of senggani stem of $39.087 \%$, senggani ethanol extract of $6.548 \%$ and ethanol extract senggani equal to $57.937 \%$, while on the positive control compared to where used vitamin $\mathrm{C}$ of $99.306 \%$. On ethanol extract on stems and flower senggani.

The average value of $\mathrm{EC}_{50}$ activity is presented in the following graph.

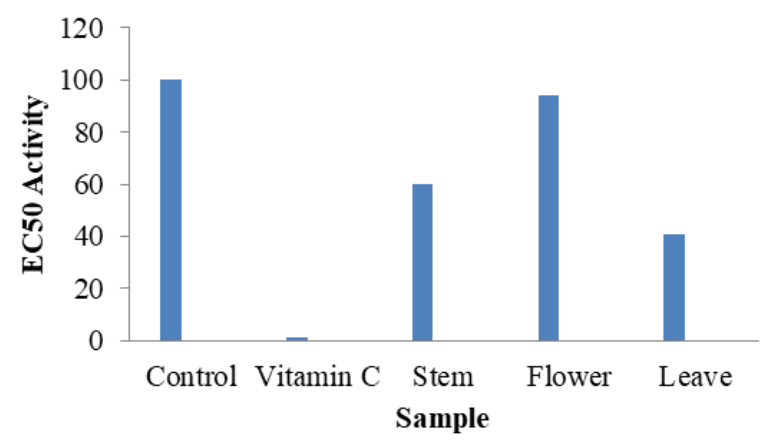

Figure 2 Antioxidant activity (EC50) of sample

We have seen that vitamin $\mathrm{C}$ as positive control has antioxidant activity with $\mathrm{EC}_{50}$ value equal to $0.694 \mathrm{ppm}$. In contrast, in ethanol extract, each sample on senggani rod got EC50 value equal to 60.913, at senggani flower $93.452 \mathrm{ppm}$ and senggani leaf $42.063 \mathrm{ppm}$. In this research. The EC50 value of $93.452 \pm 0.005 \mu \mathrm{g} / \mathrm{ml}$ for ethanol extract of senggani flower and $\mathrm{EC}_{50}$ value was $4 ., 063 \pm 0.015 \mu \mathrm{g} / \mathrm{ml}$ for ethanol extract of Senggani leaf, while $\mathrm{EC}_{50}$ value was $0.694 \pm 0,003 \mu \mathrm{g} / \mathrm{ml}$ for Vitamin $\mathrm{C}$ as positive control.

The parameter used to show the antioxidant activity is the value of the efficient concentration $\left(\mathrm{EC}_{50}\right)$, or called $\mathrm{IC}_{50}$ is the number that indicates the concentration of extract (microgram/millilitre) that can inhibit the oxidation process by $50 \%$ [6]. Specifically, a compound is said to be a very powerful antioxidant if the $\mathrm{EC}_{50}$ value is less than $50 \mu \mathrm{g} / \mathrm{ml}$, strong for $\mathrm{EC}_{50}$ is $50-100$ $\mu \mathrm{g} / \mathrm{ml}$, whereas $\mathrm{EC}_{50}$ is worth $100-150 \mu \mathrm{g} / \mathrm{ml}$ and weak if $\mathrm{EC}_{50}$ is worth $151-200 \mu \mathrm{g} / \mathrm{ml}$ [9]. Based on the calculation results, the ethanol extract in each sample has a strong antioxidant because it has an $\mathrm{EC}_{50}$ value between 50-100 $\mu \mathrm{g} / \mathrm{ml}$. Where the smaller the value of $\mathrm{EC}_{50}$, the stronger the activity as an antioxidant.

\section{CONCLUSION}

Based on the results of research that has been done, it can be concluded as follows:

The content of secondary metabolite compounds on ethanol extract from each Senggani plant sample is on Senggani trunk containing phenolic and triterpenoid 
Table 5. Percent of DPPH Radical Damping and EC50 Activity on Sample Extracts and Vitamin C

\begin{tabular}{|c|c|c|c|c|c|}
\hline Sample & Control & Vitamin C & Stem & Flower & Leave \\
\hline Deuteronomy 1 & 0.331 & 0 & 0.207 & 0.308 & 0.139 \\
\hline Deuteronomy 2 & 0.340 & 0.001 & 0.203 & 0.317 & 0.157 \\
\hline Deuteronomy 3 & 0.337 & 0.006 & 0.204 & 0.317 & 0.128 \\
\hline Average & 0.336 & 0.002 & 0.205 & 0.314 & 0.141 \\
\hline EC 50 activity & 100 & 0.694 & 60.913 & 93.452 & 42.063 \\
\hline Inhibition (\%) & 0 & 99.306 & 39.087 & 6.548 & 57.937 \\
\hline Stedev & 0.005 & 0.003 & 0.002 & 0.005 & 0.015 \\
\hline Error & 1.364 & 0.957 & 0.620 & 1.546 & 4.357 \\
\hline
\end{tabular}

compounds, on Senggani flowers containing steroid compounds and in Senggani leaves contain flavonoid and saponin compounds.

The presence of antioxidant activity on the extract from each Senggani plant samples with the value of\% damping on Senggani ethanol extract of $39.087 \%$, Senggani ethanol extract $6.548 \%$, and ethanol extract of Senggani leaf of $57.937 \%$.

The amount of antioxidant activity with DPPH freeradical damping test $\mathrm{EC}_{50}(\mu \mathrm{g} / \mathrm{ml})$ from the ethanol extract of each Senggani plant sample was $60.913 \pm$ $0.002 \mu \mathrm{g} / \mathrm{ml}$ for Senggani ethanol extract, $\mathrm{EC}_{50}$ value was $93.452 \pm 0.005 \mu \mathrm{g} / \mathrm{ml}$ for Senggani ethanol extract and $\mathrm{EC}_{50}$ value $4.063 \pm 0.015 \mu \mathrm{g} / \mathrm{ml}$ for Senggani leaf ethanol extract.

\section{REFERENCES}

[1] E.T. Arung, I.W. Kusuma, E.O. Christy, K. Shimizu, R. Kondo, Evaluation of Medicinal Plants From Central Kalimantan For Antimelanogenesis, J. of Natural Medicines, 63(4), 2009, pp. 473-480. DOI: $10.1007 / \mathrm{s} 11418-009-0351-7$

[2] E.T. Arung, W.F. Pasedan, I.W. Kusuma, M. Hendra, M.B. Supriadi, Short Communication: Selected Medicinal Plants in East and North Kalimantan (Indonesia) Against Propionibacterium acnes, J. Biodiversitas, 18(1), 2017, pp. 321-325. DOI: https://doi.org/10.13057/biodiv/d180141

[3] W. Amasa, D. Santiago, S. Mekonen, A. Ambelu, Are Cosmetics Used in Developing Countries Safe? Use and Dermal Irritation of Body Care Products in Jimma Town, Southwestern Ethiopia, Journal of Toxicology, 1(1), 2012, pp. 1-8. DOI: https://doi.org/10.1155/2012/204830

[4] D. Darwis, Teknik Dasar Laboratorium dalam Penelitian Senyawa Bahan Alam Hayati, Workshop Pengembangan Sumber Daya Manusia dalam Bidang Kimia Organik Bahan Alam Hayati, Dharmayuda, Padang, 2010.
[5] S. Wahyono, N. Supriyanti, R. Mujahid, D. Subositi, Wahyu, Jokopriambodo, National Reports Exploration Ethnomedicine Local Knowledge and Community-Based Medicinal Plants in Indonesia 2012, Publishing Agency for Health Research and Development, Indonesian Ministry of Health, Jakarta, 2013 [Indonesian]

[6] I.W. Kusuma, E.T. Arung, E. Rosamah, S. Purwatiningsih, H. Kuspradini, Syafrizal, J. Astuti, Y.U. Kim, K. Shimizu, Antidermatophyte and Antimelanogenesis Compound From Eleutherine americana Groen in Indonesia, J. Nat Med, 2010, 64, p. 223.

[7] I.W. Kusuma, Murdiyanto, E.T. Arung, Syafrizal, Y-u. Kim, Antimicrobial and antioxidant properties of medicinal plants used by the Bentian tribe from Indonesia, Food Science and Human Wellness, 3, 2014, pp. 191-196.

[8] P.K. Lunga, X. Qin, X.W. Yang, J.R. Kuiate, Z.Z. Du, D. Gatsing, Antimicrobial Steroidal Saponin and Oleanane-Type Triterpenoids Saponin From Paullinia pinnata, J. BMC Complementary and Alternative Medicine, 14(369), 2014. DOI: https://doi.org/10.1186/1472-6882-14-369

[9] K. Shimizu, Melanin Biosynthesisn Inhibitory Compounds From Artocarpus heteropphylius Dissertation, Kyushu University, Japan, 2006.

[10]H.D. Salusu, F. Ariani, E. Obeth, M. Rayment, E. Budiarso, I.W. Kusuma, E.T. Arung, Phytochemical Screening and Antioxidant Activity of Kokang (Lepisanthes amoena) Fruit, J. Agrivita, 39(2), 2017, pp. 214-218. 